\title{
CrimRxiv
}

\section{Fresh Perspectives on the "War on Terror"}

\author{
Miriam Gani, Penelope Mathew
}

Published on: Mar 04, 2022

DOI: $10.21428 / c b 6 a b 371.40 e 576 a b$

License: Creative Commons Attribution 4.0 International License (CC-BY 4.0). 
